\title{
Distribution and morphometric characters of the Mediterranean brown ray, Raja miraletus (Chondrichthyes: Rajidae) in the Gulf of Gabes (Tunisia, Central Mediterranean)
}

\author{
Hasna Kadri ${ }^{1,2}$ *, Sondes Marouani ${ }^{1,2}$, Mohamed Nejmeddine Bradai ${ }^{1}$, Abderrahmen Bouaïn ${ }^{2}$, \\ Eric Morize ${ }^{3}$
}

${ }^{1}$ Institut National des Sciences et Technologies de la Mer, Centre de Sfax, B.P. 1035, Sfax 3018, Tunisie

${ }^{2}$ Faculté des Sciences de Sfax, B.P. 802, Sfax 3028, Tunisie

${ }^{3}$ Lemar/ IRD 230 Broennou, 29870 Landéda, France

Email address:

hasnakadri@yahoo.fr (H. KADRI)

\section{To cite this article:}

Hasna Kadri, Sondes Marouani, Mohamed Nejmeddine Bradai, Abderrahmen Bouaïn, Eric Morize. Distribution and Morphometric Characters of the Mediterranean Brown Ray, Raja Miraletus (Chondrichthyes: Rajidae) in the Gulf of Gabes (Tunisia, Central Mediterranean). American Journal of Agriculture and Forestry. Vol. 2, No. 2, 2014, pp. 45-50. doi: 10.11648/j.ajaf.20140202.15

\begin{abstract}
To determine some morphometric characters of the Mediterranean brown ray Raja miraletus Linnaeus, 1758 in the Gulf of Gabes (Tunisia), samples were analysed and described on data from the commercial trawl at monthly intervals between December 2006 and January 2007. A total of 501 male and 629 female specimens were collected during the sampling period. The largest (in terms of Total length: TL) female and male were $58 \mathrm{~cm}$ and $56 \mathrm{~cm}$, respectively. Some various morphmetric characters were measured. Relationships between the characters were defined separately for both sexe. Morphometric characters were strongly correlated with total length but the nature of allometry differed according to the characters.
\end{abstract}

Keywords: Raja Miraletus, Morphometric and Numeric Characters, Gulf of Gabes, Mediterranean Sea

\section{Introduction}

Skates (order Rajiformes) are one of the most speciose elasmobranch orders and include at least 27 genera and more than 245 species (Ebert and Compagno 2007). Skates are important elements of the marine biodiversity, but they are highly vulnerable to commercial Exploitation (Barbara 2010). The brown ray, Raja miraletus Linnaeus, 1758 is a medium-sized skate inhabiting the Mediterranean Sea and the western African coast (Séret and Opic 1990; Serena et al. 2010). Despite the increasing fishing pressure, there is a paucity of information on the life history of $R$. miraletus resulting in an assessment of "minor preoccupation' on IUCN Red List assessments for chondrichthyans in the Mediterranean Sea (Cavanagh and Gibson 2007).

Information on distribution species is reported for some Mediterranean areas (Capapé and Quignard 1974a; 1974b; 1975; Capapé and Azouz 1975; Abdel-Aziz
1992; and Relini et al. 1999) including the Central Adriatic Sea (Zupanovic 1961; Jardas 1973; Jardas 1981), but data from Southern Tunisia are scanty. Therefore, morphometric conversions are particularly helpful when, for example, a specimen is damaged, or when dealing with commercially preprocessed specimens, in which not all morphometric traits can be measured. As conversion factors differ between species, they may also serve as a tool for species identification, or for accurate identification of problematic specimens. This is particularly important at landing ports where fish need to be identified on site.

In the present paper some features of the brown ray biology in the Southern Adriatic are reported, in order to add information referring to the just mentioned basin. These data were compared with results from other Mediterranean marine areas, in order to highlight possible intraspecific variations of life parameters among different populations. The present work focuses on some morphometric characters. 
The present study aimed to (i) estimate relationships between different body measurements to increase the information available for the brown ray in Tunisian waters, and (ii) investigate the ability of these measurements to discriminate between species to provide additional tools for assisting in the identification of R.miraletus on the Gulf of Gabes.

This study reported the first description of biometric relationships for $R$. miraletus, which would be useful for the sustainable conservation of this rear fishery in the Gulf of Gabes and also other countries.

\section{Materials and Methods}

\subsection{Study Area}

The Gabes region is located in southern Tunisia and in southern Mediterranean Sea. It extends along $750 \mathrm{~km}$ representing $58 \%$ of the Tunisian coast (Bradai et al. $1992)$. It ex- tends from the city of Chebba $\left(35.3^{\circ} \mathrm{N}\right)$ in the north of the region to the Island of Djerba $\left(33.8^{\circ} \mathrm{N}\right)$ in the south, a distance of $200 \mathrm{~km}$. In breadth, it extends from $10^{\circ} \mathrm{E}$ to just under $11.2^{\circ} \mathrm{E}$. The annual cycle of water temperature is very pronounced $\left(13^{\circ} \mathrm{C}\right.$ to $\left.29^{\circ} \mathrm{C}\right)$ and resembles that of a lagoon. In summer, the particularly high temperatures and salinities (38 to 39) lead to the appearance of red algae. It was recorded with high concentrations in summer (47-48\%) and often in winter (40-42\%o). The obtained data set was registered and maps of population distribution were drawn. The second important feature of the Gulf of Gabes is the amplitude of the high tide which attains $1.8 \mathrm{~m}$, the highest in the Mediterranean.

\subsection{Sex Ratio and biological sample}

A total of $1130 R$. miraletus specimens were collected monthly in the Gulf of Gabes between December 2006 and January 2007 from commercial bottom-trawl landings in the Gulf of Gabes and using a beam trawl lasted for $2 \mathrm{~h}$, during both day and night. Specimens were captured using a 22-mm stretched-mesh size cod-end, operating at over $30 \mathrm{~m}$ depth (Figure 1).

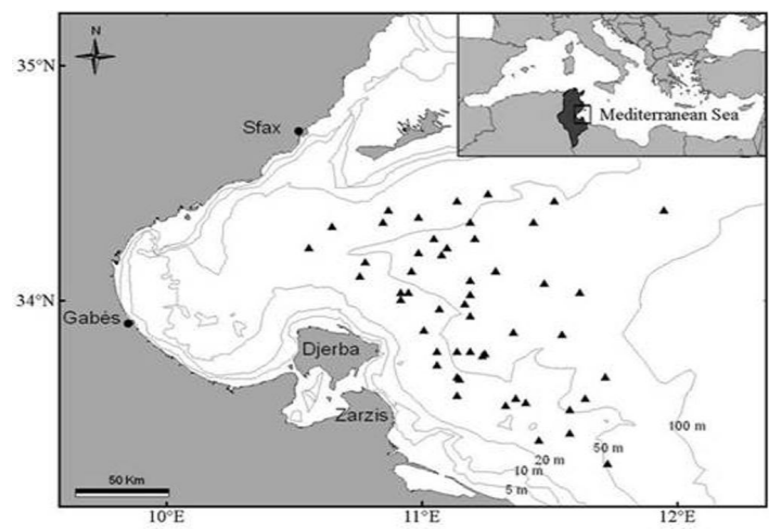

Figure 1. Map of the study area, indicating the sampling location (Gulf of Gabes, Southern Tunisia, Central Mediterranean).
The authority responsible for a national park gave us permission to collect these samples and for this work studies did not involve endangered or protected species.

The sex ratio according to fish size provide a useful tool to examine the biological characteristics of the fish species, such as sexual inversion, longevity in relation to sex, vulnerability to fishing gear and the spatial, seasonal and even daily distribution of species. With the numerical abundance by sex, the following ratio was done by computing (Anato 1999).

The sex ratio was expressed as the number of males/number of both sexes combined. A Chi- square test ( $\chi 2)$ was used to examine the homogeneity of the sex ratio. On the other hand, the size frequency was analyzed at a 5 $\mathrm{cm}$ interval standard length class using a histogram to determine the type of distribution, which characterizes the fish population. Length-frequency distributions of females and males were compared using the Kolmogorov-Smirnov two-sample test.

\subsection{Morphometric characters measurement}

The (TL) was measured to the nearest centimeter. The total body mass (TM) of each specimen was weighted to the nearest 10 and $0.01 \mathrm{~g}$ respectively for large and small Specimens. Numeric characters tooth were also counted directly on specimens by making incisions at the jaw angles to expose the teeth, the tooth shape was noted (the number of the Tooth rows lower, the number of the tooth rows upper jaw, number of pectoral fin rays (NP), number of nictitating lamellae (NL), number of pseudo-branchial lamellae (NPL), the number of the trunchal vertebrae. The parameters of distribution (average) and parameters of dispersion (minimum, maximum, ecartype, interval of confidence) of this morphometric characters were calculated.

\section{Results and Discussion}

This study provides morphometric information for the Mediterranean brown ray Raja miraletus in southern Tunisian waters (Gulf of Gabes). A total of 1130 Raja miraletus collected 629 were females (13.5-56 cm TL; [8.5 to $35 \mathrm{~cm} \mathrm{DW]} \mathrm{and} \mathrm{7-980g} \mathrm{TM)} \mathrm{whereas} 501$ were males (13.5-58cm TL; [9 to $37 \mathrm{~cm} \mathrm{DW];} \mathrm{8-850g} \mathrm{TM).} \mathrm{Although}$ males and females covered similar length ranges, the distribution of length within these ranges was significantly different (Kolmogorov-Smirnov test, $\mathrm{D}=0.088, \mathrm{n}=1130$, $\mathrm{p}=0.02$ ) (Figure 2). The variation in the proportion of both sexes, depending on the size, showed a highly significant difference $\left(\chi^{2}\right.$ cal $\left.=137.37, \mathrm{P}<0.001\right)$. There was no significant difference in the regression slopes between sexes for the TL and DW relationship (ANCOVA, F1, $1167=3.13, \mathrm{P} \square 0.05$ ) (Figure 3). The combined sex TL and DW (cm) relationship is described by (Figure 3 ). The TMTL relationships was significantly different between sexes (ANCOVA, F1, 1151= 29.17, $\mathrm{P}<0.05$ ) (Figure 4). Therefore, the nonlinear relationship of TL-TM is presented separately for each sex. 


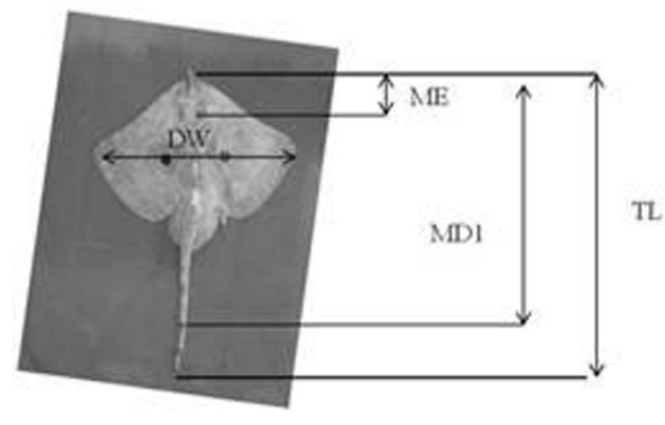

Face dorsale

Figure 2. Measurements made on Raja miraletus.

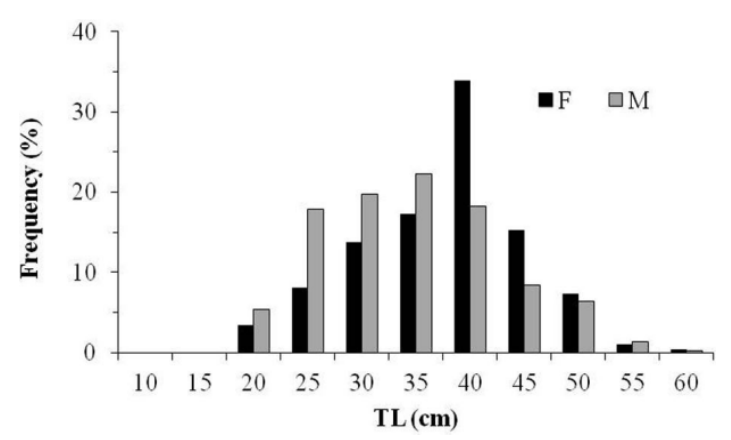

Figure 3. Length-frequency distributions (5 $\mathrm{cm}$ length classes) of female and male Raja miraletus sampled in Gulf of Gabes (Tunisia).
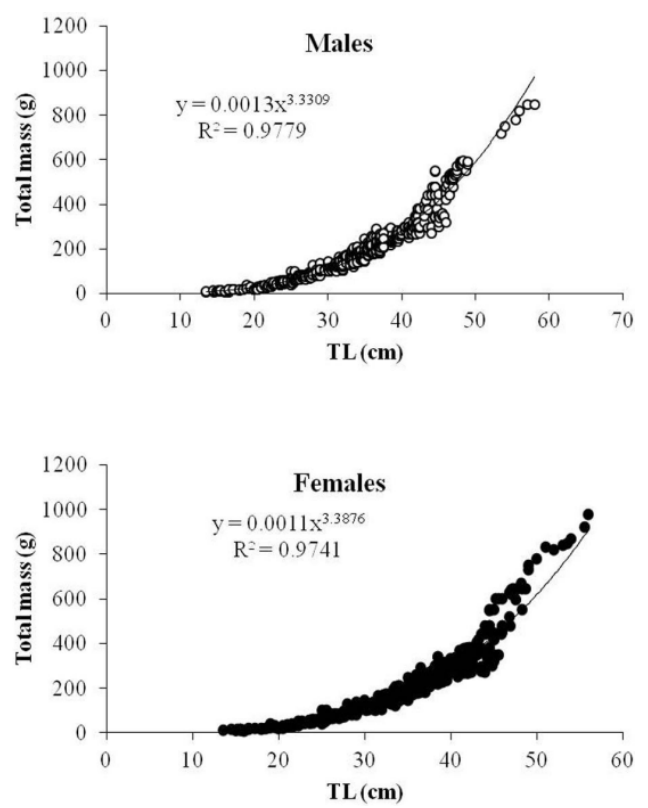

Figure 4. Relationship between Total length (TL) and Total mass (TM) of Raja miraletus in the Gulf of Gabes (Tunisia). $r^{2}=$ Coefficient of determination.

A study led by Ungaro in 2004 showed that in the Southern Adriatic Sea (Mediterranean basin), there are not significant differences in length-weight between sex. The same indication came from Stergiou and Moutopoulos (2001), while other authors report two different curves (male and female) (Jardas 1973; Capapé and Quignard 1974a; Relini et al. 1999). The length/width-weight relationships have many benefits for indicators of the condition and can be used to calculate biomass and to estimate the recovery of edible meat from crabs of various sizes (Lagler 1968). Previously, we demonstrated that differences in growth between sexes are a common feature in Raja species. Females typically attain larger size than males, but they grow more slowly (Kadri et al. 2012; 2013 a; 2013 b). It is important to mention that weight-size relationships can provide useful information about the increase in weight of a population and this parameter could also be important for comparative studies between populations (Mori et al. 1990).

This study provides morphometric information for the Mediterranean brown ray Raja miraletus in southern Tunisian waters (Gulf of Gabes). The number of females in all seasons was higher than males, there is statistical significance (Table 1). Our results are in accordance with Capapé et al. 2010 who reported a 1:0.95 ratio of male and female of $R$. miraletus on the coast of Senegal (eastern tropical Atlantic). Similarly, (Ezzat et al. 1987) shown higher numbers of females sampled in Mediterranean waters of Alexandria in each month. The sex ratio in Southern Adriatic basin is an expected result of 1:1.39 in favor of females (ungaro 2004).

Table 1. Variation in the proportion of male and female Raja miraletus according to season in the Gulf of Gabes (Tunisia), and comparison through a t-Student test ( $p<0.05$; bold values: statistically different). NS: not significant, SS: significant).

\begin{tabular}{llllll}
\hline & Summer & Autumn & Winter & Spring & Annual \\
\hline Males & 148 & 111 & 122 & 120 & 501 \\
Females & 154 & 158 & 173 & 144 & 629 \\
Total & 302 & 269 & 295 & 264 & 1130 \\
\%Males & 27.25 & 35.35 & 48.72 & 46.08 & 37.02 \\
\%Females & 50.99 & 58.74 & 58.64 & 54.55 & 55.66 \\
$\mathrm{X}^{2}$ cal & 0.12 & 8.21 & 8.82 & 2.18 & 11.91 \\
$\mathrm{P}$ & 0.73 & 0.004 & 0.003 & 0.14 & $<0.001$ \\
significance & $\mathrm{NS}$ & $\mathrm{NS}$ & $\mathrm{NS}$ & $\mathrm{NS}$ & $\mathrm{SS}$ \\
\hline
\end{tabular}

In our study, these individuals were measured 13.5 to 58 $\mathrm{cm}$ in Total length, 8.5 to $37 \mathrm{~cm}$ in disk width and 7 to 980 $\mathrm{g}$ in weight. In the Gulf of Tunis (Capapé and Quignard 1974a), Raja miraletus was measured 32 to $33 \mathrm{~cm}$ in the maximum disk width, 54 to $57 \mathrm{~cm}$ in maximum total length of males and females respectively, and 151 to $1338 \mathrm{~g}$ in weight. The (TL) range was $165-510 \mathrm{~mm}$ and $150-495 \mathrm{~mm}$ TL for female and male individuals respectively, and the weight ranged between 20-750g in the Southern Adriatic basin (Ungaro 2004), but in Senegalese coast, the weight for R.miraletus was 1205 to $1336 \mathrm{~g}$ (Capapé et al. 2007).

The $\mathrm{b}$ value for the weight/ total length relationship for female Raja miraletus sampled in this study (3.38), and were higher than that for males (3.33). Ungaro 2004 reported a positive allometric growth pattern of $R$. miraletus (146 individuals) collected from the Southern Adriatic basin.

The $b$ values vary according to species, sex, age, seasons 
and feeding. Furthermore, many parameters were described to affect the $b$ growth exponent such changes in physiological conditions or different amounts of available food life span or growth increment (Le Cren 1951; Ricker 1975).

Weight-size relationships can provide useful information about the increase in weight of a population and is also important for comparative studies between populations (Mori et al. 1990).

The maximum size for males and females in this work
(65 and $80 \mathrm{~cm} \mathrm{TL}$, respectively) is greater than the previously recorded maximum size in other studies (Capapé and Quignard 1974a; Consalvo et al. 2010).

Morphometric characters were strongly positively correlated except for TL-LD and LT-MO and show negative allometric growth (figures 4 and 8). Other numeric counts characters are also presented (Table 2).

In this study, the counts of numeric caracters for R.miraletus were similar with results observed in the Gulf of Tunis (Capapé and Quignard 1974 a) (Table 3).

Table 2. Morphometric characters of the Mediterranean brown ray (Raja miraletus) in the Gul of Gabes (Tunisia). number of nictitating lamellae $(N L)$, number of pectoral fin (NP), number of pseudobranchial lamellae (NPL), number of the Tooth rows (NT) (upper jaw, lower jaw), minimum (Min), maximum (Max) and average Mean $\pm S E$.

\begin{tabular}{cccccccc}
\hline Parameters & NV & (NL) & (NP) & (NPL) & \multicolumn{2}{c}{ upper jaw } & lower jaw \\
\hline Min & 22 & 11 & 77 & 10 & 28 & 32 \\
Max & 26 & 13 & 84 & 15 & 44 & 44 \\
Mean \pm SE & $23.24 \pm 0.44$ & $12.14 \pm 0.14$ & $78.96 \pm 0.34$ & $12.28 \pm 0.25$ & $36.48 \pm 0.95$ & $37.47 \pm 0.68$ \\
\hline
\end{tabular}

Table 3. Comparison of numeric counts various of other studies in the Mediterranean.

\begin{tabular}{|c|c|c|c|}
\hline & $\begin{array}{l}\text { Capapé and Quignard } \\
\text { (1974) (Gulf of Tunis) }\end{array}$ & $\begin{array}{c}\text { Quignard (1965) (Gulf of } \\
\text { Tunis) }\end{array}$ & $\begin{array}{c}\text { Present study (Gulf of } \\
\text { Gabes) }\end{array}$ \\
\hline Number of the trunchal vertebrae & $24-26$ & $23-25$ & $22-26$ \\
\hline Number of the nictitating lamellae (NL) & $11-13$ & & $11-13$ \\
\hline Number of the pectoral fin (NP) & $76-80$ & $76-79$ & $77-84$ \\
\hline Number of pseudobranchial lamellae (NPL) & $12-14$ & $10-12$ & $10-15$ \\
\hline Number of the upper jaw & $38-48$ & $41-49$ & $28-44$ \\
\hline Number of the lower jaw & $40-50$ & $40-43$ & $32-44$ \\
\hline
\end{tabular}
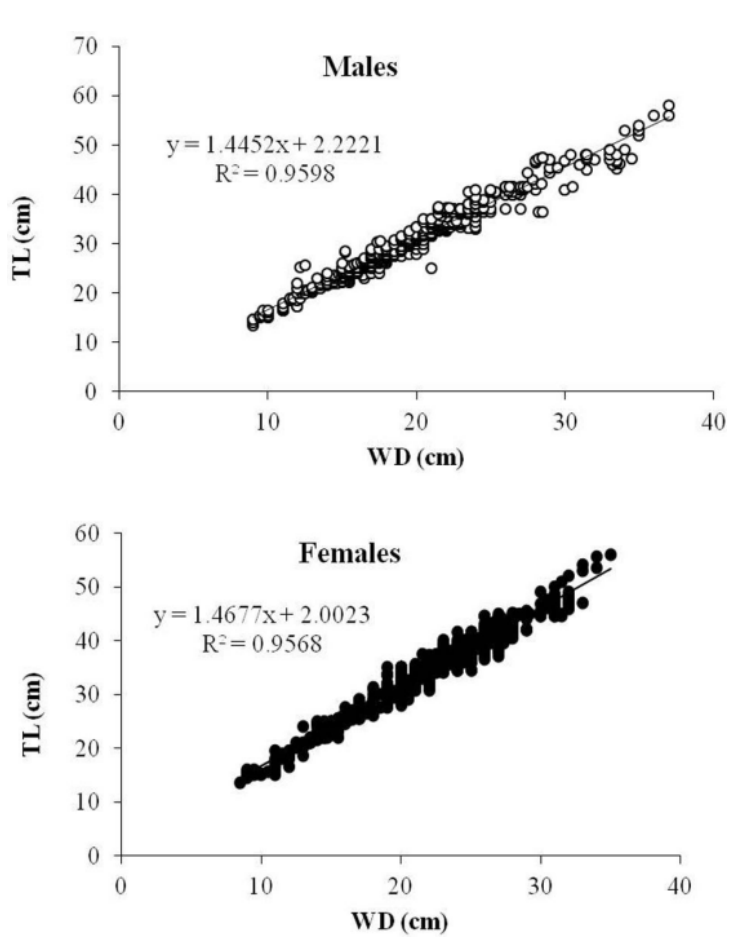

Figure 5. Relationship between Total length (TL) and Disc width (DW) of Raja miraletus in the Gulf of Gabes (Tunisia). $r^{2}=$ Coefficient of determination.
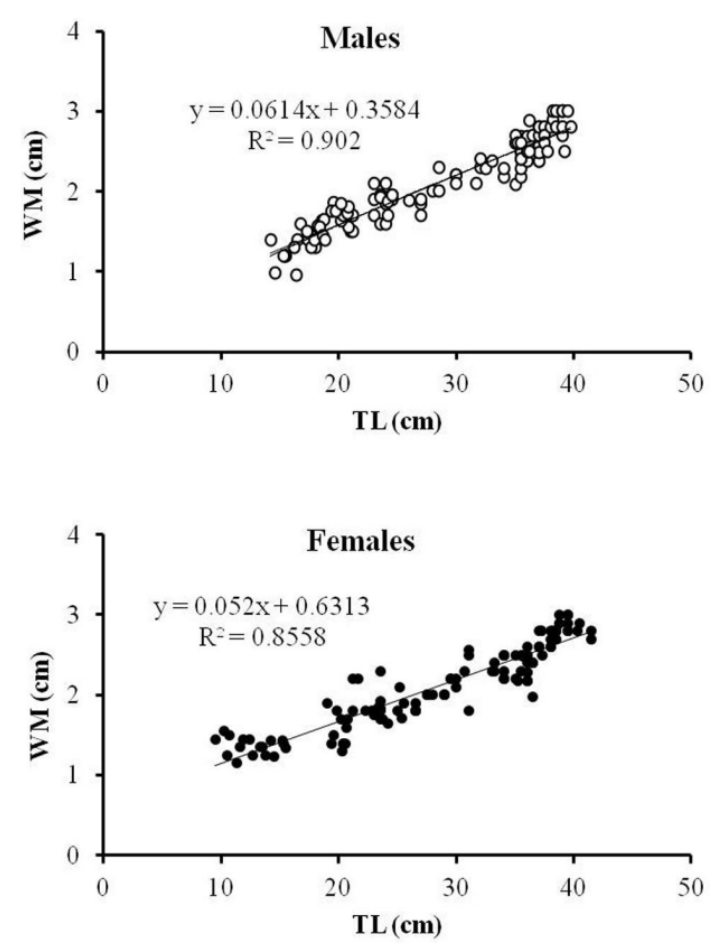

Figure 6. Relationship between Total length (TL) and snout tip to eye (SE) of Raja miraletus in the Gulf of Gabes (Tunisia). $r^{2}=$ Coefficient of determination. 

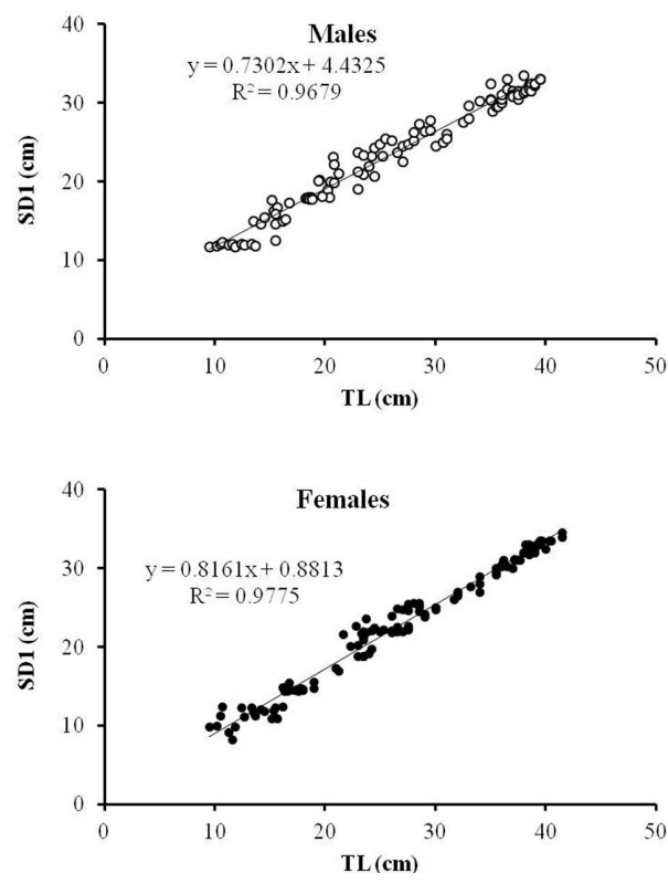

Figure 7. Relationship between Total length (TL) and width of the mouth (WM) of Raja miraletus in the Gulf of Gabes (Tunisia). $r^{2}=$ Coefficient of determination.
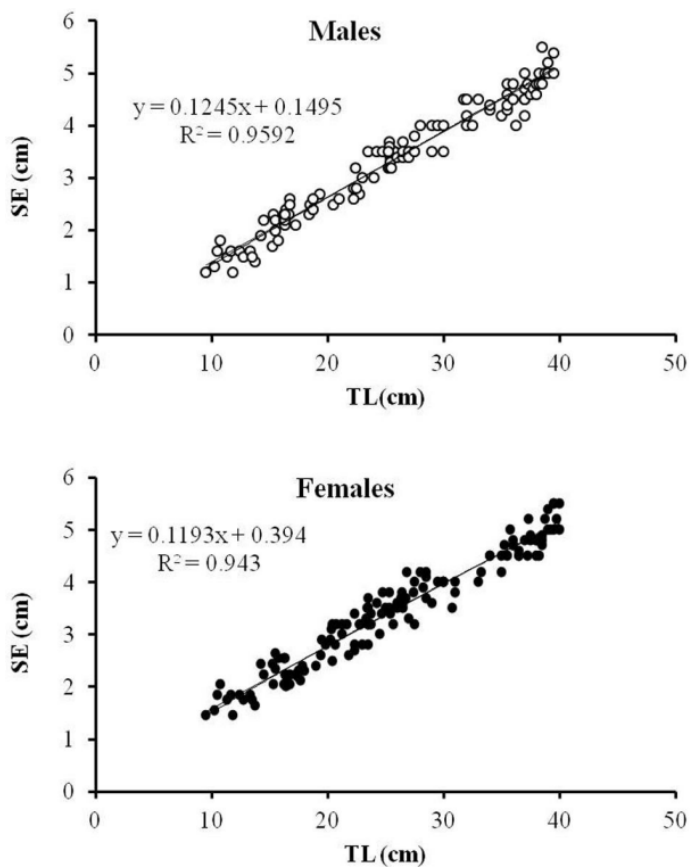

Figure 8. Relationship between Total length (TL) and snout tip to first dorsal (SDI) of Raja miraletus in the Gulf of Gabes (Tunisia). $r^{2}=$ Coefficient of determination.

In conclusion, this study shows that there was a strong relationship between DW, SE, WM, SD1, H and TL for the $R$. miraletus population in the Gulf of Gabes in southern Tunisia.

This study would be an effective tool for fishery biologists, managers and conservationists to initiate management strategies and regulations for the sustainable conservation of the remaining stocks of this species in the
Gulf of Gabes (Southern Tunisia) ecosystem. In addition, results of this study provide invaluable information for the online FishBase database, as well as an important baseline for further studies.

\section{Acknowledgements}

This work was undertaken with the aid of funds provided by National Institute of Sciences and Technologies of the sea (INSTM, Sfax Center). The authors are also grateful to the anonymous referees whose suggestions and comments improved the submitted manuscript.

\section{References}

[1] Abdel-Aziz SH (1992). The use of vertebral rings of the brown ray Raja miraletus (Linnaeus 1758) off the Egyptian Mediterranean coast for estimation of age and growth. Cybium. 16: 121-132.

[2] Anato CB (1999). Les Sparidae des côtes béninoises: milieu de vie, pêche, presentation des espèces et biologie de Dentex angolensis Poll et Maul, 1953, Thèse de Doctorat d'Etat Sciences, Fac. Sci. 1060 Tunis, 277 pp.

[3] Babara Serra-Pereira, Ines Farias, Teresa Moura, Leonel Serrano Gordo, Miguel Santos and Ivone Figueiredo (2010). Morphometric ratios of six commercially landed species of skate from the Portuguese continental shelf, and their utility for identification ICES J. Mar.Sc. 67: doi:10.1093/icesjms/fsq056.

[4] Bradai MN, Ghorbel M, Bouain A and Abdelmouleh A (1992). Observations ichtyologiques effectuées dans la région du golfe de Gabès (Tunisie). Bull. Inst. Natl. Sci. Tech. Oceanogr. Peche Salammbo. 19: 57-65.

[5] Capapé and Azouz (1975). Etude du régime alimentaire de deux raies communes dans le golfe de Tunis: Raja miraletus Linné, 1758 et R. radula, Delaroche, 1809. Arch. Inst. Pasteur, Tunis. 52: 233-250.

[6] Capapé C and Quignard (1974a). Contribution à la biologie des Rajidae des côtes tunisiennes. I. Raja miraletus Linné, 1758: Répartition géographique et bathymétrique, sexualité, reproduction, fécondité. Arch. Inst. Pasteur, Tunis. 51(1-2): 39-60.

[7] Capapé C and Quignard JP (1974b). Contribution à la biologie des Rajidae des ôtes tunisiennes. XVI. Raja miraletus Linné, 1758: relations taille-poids du foie, poids $\mathrm{du}$ corps, poids des gonades, coefficient de condition, rapports hépato- et gonadosomatique. Ann. Inst. Michel Pacha. 10: 19-46.

[8] Capapé C and Quignard JP (1975). Essai d'évaluation de la fécondité chez les Sélaciens ovipares: cas de Raja miraletus Linné, 1758 et R. radula Delaroche, 1809 des côtes tunisiennes. Arch. Inst. Pasteur, Tunis. 52: 263-276.

[9] Capapé C, Diatta Y, Ndiaye P, Reynaud C and Oddone MC (2010). New biological data on the brown ray, Raja miraletus (Chondrichthyes: Rajidae), off the coast of Senegal (eastern tropical Atlantic).Cienc. Mar. 36(3): 301309 . 
[10] Capapé C, Guélorget O, Siau Y, Vergne Y and Quignard JP (2007). Reproductive biology of the thornback ray Raja clavata L., 1758 (Chondrichthyes: Rajidae) from the coast of Languedoc (southern France, northern Mediterranean). Vie Milieu 57: 83-90.

[11] Cavangh RD and Gibson C (2007). Overview of the Conservation Status of Cartilaginous Fishes (Chondrichthyans) in the Mediterranean Sea. IUCN, Gland (Switzerland) and Malaga, 50p.

[12] Consalvo I, Iraci Sareri D, Bottaro M, Tudisco A, Cantone G and Vacchi M (2010). Diet composition of juveniles of rough ray Raja radula (Chondrichthyes: Rajidae) from the Ionian Sea. Ital. J. Zool. 77: 438-442.

[13] Ebert DA and Compagno LJV (2007). Biodiversity and systematic of skates (Chondrichthyes: Rajiformes: Rajoidei). Environ. Biol. Fish. 80: 111-124.

[14] Ezzat A, Abdel-Aziz SH, El-Charabawy MM and Hussein MO (1987). The food of Raja miraletus Linnaeus, 1758 in Mediterranean waters off Alexandria. Bull. Inst. Oceanogr. Fish. Cairo, 13: 59-74.

[15] Jardas I (1973). A contribution to our knowledge of the biology and ecology of thornback ray (Raja clavata L.) and brown ray (Raja miraletus L.) in the Adriatic. Acta Adriat. 15(3): $1-42$

[16] Jardas I (1981). Morphometric characteristics of the brown ray, Raja (Raja) miraletus L. (Pisces, Chondrichthyes) in the Adriatic Sea. Biosistematika. 7(2): 159-171.

[17] Kadri H, Marouani S, Saïdi B, Bradai MN, Ghorbel M, Bouaïn A and Eric M (2012). Age, growth and reproduction of Raja miraletus (Linnaeus, 1758) (Chondrichthyes: Rajidae) of the Gulf of Gabès (Tunisia, Central Mediterranean Sea). Mar. Biol. Res. 8: 309-317.

[18] Kadri H, Marouani S, Saïdi B, Bradai MN, Ghorbel M, Bouaï A and Eric M (2013a). Age growth and reproductive biology of the rough skate, Raja radula (Chondrichthyes: Rajidae), off the Gulf of Gabes (southern Tunisia, central Mediterranean). Mar. Fres. Res http://dx.doi.org/10.1071/MF12218.
[19] Kadri H, Marouani S, Saïdi B, Bradai MN, Ghorbel M, Bouaïn A and Eric M (2013b). Age, growth and reproductive biology of the rough skate, Raja clavata (Chondrichthyes: Rajidae), off the Gulf of Gabes (southern Tunisia, central Mediterranean). Mar. Biol. Res. http://dx.doi.org/10.1080/17451000.2013.797584.

[20] Lagler KF (1968). Capture, Sampling and Examination of Fishes, in Ricker, eds, Methods for Assessment of Fish Production in Fresh Waters, IBP Handbook No:3, Blackwell Scientific Publication. Oxford.

[21] Le Cren ED (1951). The Length-Weight Relationships and Seasonal Cycle in Gonad Weight and Condition in Perch (Perca fluviatilis). J. Anim. Ecol. 20: 210-219.

[22] Mori M, Manconi R and Fanciulli G (1990). Notes on the reproductive biology of Carcinus aestuarii Nardo (Crustacea, Decapoda) from the lagoon of San Teodoro (Island of Sardinia, Italy). Riv. Idrobiol. 29: 763-774.

[23] Relini G, Bertrand J and ZAMBONI A (1999). Synthesis of the knowledge on bottom fishery resources in Central Mediterranean (Italy and Corsica). Bio 1. Mar. Medit. 6(suppl. 1): 868.

[24] Ricker WE (1975). Computation and interpretation of biological statistics of fish populations. Bull. Fish. Res. Board. Can. 191: 1-382.

[25] Serena F, Mancusi C and Barone M (2010). Field identifcation guide to the skates (Rajidae) of the Mediterranean Sea. Guidelines for data collection and analysis. Biol. Mar.Medit. 17(Suppl. 2): 204 pages.

[26] Séret B and Opic, P (1990). Poissons de mer de l'ouest africain tropical. Init.-Doc., 49. Paris: ORSTOM, 416 pp.

[27] Stergiou KI and Moutopoulos DK (2001). A review of length-weight relationships of fishes from Greek marine waters. Naga, ICLARM Quat. 24(1-2): 23-39.

[28] Ungaro N (2004). Biological parameters of the brown ray Raja miraletus in the southern Adriatic Basin. Cybium. 28: 174-176.

[29] Zupanovic S. 1961. Contribution à la connaissance des poisons de l'Adriatique. Acta Adriatica 9:1-84. 